\title{
Jurisdiction Analysis of The Distribution of Integrity Children Out of Marriage as Substitute Heritages \\ (Study of The Supreme Court Decision Number: 784 K/Pdt/2014)
}

\section{Gagah Hotma Parulian Siregar, Widhi Handoko}

dashsiregar@gmail.com

1 and 2 Notary Masters Study Program, Faculty of Law, Diponegoro University

\begin{abstract}
Many problems regarding inheritance law occur due to distribution that is not in accordance with applicable regulations. In the Supreme Court Decision Number 784 K/Pdt/2014, the main research problems are: (1) How is the distribution of the inheritance of children out of wedlock as replacement heirs based on the Civil Code study of the Supreme Court's decision number: 784 K/Pdt/2014 . (2) Is the content of the Supreme Court's order Number: 784/Pdt/2014 concerning the distribution of the inheritance of children out of wedlock as replacement heirs appropriate or not according to the Civil Code. This type of research is normative juridical. The data used are secondary data, library study data collection and qualitative data analysis and deductive method conclusions. The conclusion of this decision study states that (1) the heirs to the inheritance of the Supreme Court decision study number: 784 K/Pdt/2014 are Dewina Tjandra, Trisnani Tjandra, Patty Tjandra, Sarina Tjandra, Arifin Tjandra, Ony Tjandra, and Fitri Tjandra . (2) The Supreme Court's decision Number $784 \mathrm{~K} / \mathrm{Pdt} / 2014$ regarding the distribution of the inheritance of children out of wedlock as substitute heirs is not in accordance with Article 842 of the Civil Code.
\end{abstract}

Keywords: inheritance law; western civil inheritance law; division of property

\section{Introduction}

Humans as creatures created by God Almighty who are made of the sexes of men and women, according to their nature. They live in pairs between men and women who are bound in marriage ropes who then give birth to children so that the smallest community unit is formed which is called the family. In Indonesia, marriage is a sacred and noble thing, as formulated in Article 1 of Law Number 1 of 1974, "Marriage is an outer and inner bond 
between a man and a woman as husband and wife with the aim of forming a happy and eternal family. based on God Almighty"(Law of the Republic of Indonesia, 1974). Therefore, with marriage, it is expected to form a prosperous family, because in the family it can create a healthy generation and later will be able to become reliable and resilient human resources so that they can advance the life of the Indonesian nation.

Marriage is an attempt to maintain survival and protect offspring. But sometimes the marriage is often tarnished by the presence of an adultery or relationship outside of marriage. Often the adultery relationship produces an illegitimate offspring, so that children born out of wedlock have the status of illegitimate children (Hilman, 2007). In Article 43 paragraph 1 of the Marriage Law Number 1 of 1974 concerning Marriage, it is stated that "children out of wedlock only have a civil relationship with their mother and their mother's family". Thus, an illegitimate child as a result of an adultery committed by both parents only has a civil relationship with his mother and his mother's family and will not get the same rights as the rights of a legitimate child, especially in terms of inheritance. Children out of wedlock will not be able to inherit from their father until there is acknowledgment from their father(War, 2011). Even though it is not the desire of the illegitimate child to be born from the result of adultery, therefore the law has provided a protection for the illegitimate child, especially in terms of inheritance.(Darmabrata, 2009).

Inheritance law is one part of civil law as a whole and is the smallest part of family law. Inheritance law is closely related to the scope of human life, because every human being will experience a legal event called death. The legal consequences that arise due to the occurrence of a legal event of a person's death, including the problem of how to manage and continue the rights and obligations of a person who dies.(Suparman \& Gunarsa, 2005). Civil inheritance law is very closely related to family law, therefore in studying inheritance law it is also necessary to study the inheritance law system in terms 
of kinship, inheritance system, and the form of the inheritance. The family system in civil inheritance is a bilateral and parental family system, namely a system that draws lineage from both parents, both paternal and maternal.(Jamal, 2016). The inheritance system regulated in the civil inheritance law is an individual system, where the heirs inherit individually or individually and the heirs are not distinguished, both men and women, where men and women have the same inheritance rights. If a person dies, by law and at that time his rights and obligations are transferred to his heirs as long as the rights and obligations are included in the legal field of property or rights and obligations that can be valued in money.(Ali, 2000).

In terms of inheritance, civil inheritance law distinguishes between direct heirs and direct heirs by replacing. Direct heirs are heirs who inherit because of their own position and act on their own. Based on Article 841 of the Civil Code. Substitute heirs are heirs who receive inheritance not because of their own position, but because of a replacement to act as a substitute in degree and in all the rights of the person being replaced.(Subekti \& Tjitrosudibio, 1992). In western civil inheritance law, those who can become substitute heirs are those who have legal relations as legal descendants of the replaced heirs. Therefore, civil inheritance law recognizes three kinds of replacement, namely as follows:(Meliala, 2018):

1. Substitution in a straight line down

Each succession in a straight line downwards, continues without end in all matters of substitution as above as long as it is permitted, both in the case when several children of the deceased inherit together with the descendants of the first child, or all of their descendants inherit together. sama, each other in family ties of varying degrees(Pitlo, Kasdorp, \& Arief, 1979).

2. Substitution in a line to the side 
In a side line, succession is allowed for the benefit of all children and descendants of brothers and sisters who have died first, whether they be inherited together with their uncles or aunts, or the inheritance after the death of all the relatives of the deceased must be divided first. among all their descendants, which are related to each other in unequal degrees(Satrio, 1992).

3. Substitutions in the line to the side deviate

Substitution in a deviant line is also allowed for inheritance for nieces and nephews, in the event that in addition to nephews who are related to the closest blood relatives to the deceased, there are still children and descendants of brothers or sisters from whom the relatives died first.(Tamakiran, 2004).

In terms of replacement, according to Prof. MA Pitto, it is based on Article 842 of the Civil Code which states that replacement as an heir is only by legitimate descendants.

Through this background, a number of problems will be formulated, namely how to divide the inheritance of children out of wedlock as substitute heirs based on the Civil Code study of the Supreme Court's decision number: $784 \mathrm{~K} / \mathrm{Pdt} / 2014$. Then furthermore, whether the contents of the Supreme Court's order Number: 784/Pdt/2014 regarding the distribution of the inheritance of children out of wedlock as substitute heirs are appropriate or not according to the Civil Code.

Research on Juridical Analysis of the Distribution of Inheritance of the late Djaja Tjandra and the late Masri Tansa according to the Civil Code (Case Study Decision Number $784 \mathrm{~K} / \mathrm{Pdt} / 2014$ ) is an original and accountable research, researchers have made comparisons to a number of previous studies that describe the writing. The research is the same in this study but has a different substance, namely the research carried out by a researcher who has the name Yuandha Kurnia Setiawan where the title of the research isis Juridical 
Analysis of the Division of Inheritance of the Late. Lumbangaol To His Heirs Based On The Provisions Of The Civil Code (Study Decision No. 580/Pdt.G/2015/Pn Mdn.)" In his research, he focuses more on the distribution of inheritance to the heirs accompanied by a decision study(Setiawan \& Keumala, 2019).The research was conducted by a researcher named Umar Haris Sanjaya with the title of his research "The Position of Wills Against Inheritance Assets That Have Not Been Distributed To Heirs". In his research, the researcher focuses on the implementation of the will which must be immediately distributed to the beneficiary(Sanjaya, 2018). Research conducted by a researcher named Bistamam with the title of his research "Juridical Review of the Distribution of Inheritance for Heirs of Different Religions and Inheritance Viewed from Islamic Law and Civil Law". The researcher focuses his research in terms of the distribution of inheritance with religious differences(Bistamam, Lestari, \& Hasanah, 2016).

The journal written by this author has differences with the journals or studies above. The journal written by this author discusses the distribution of inheritance that must be given to the heirs in accordance with the decisions that have been listed.

The approach method used by the author when completing the legal writing is "juridical normative, namely the approach method used to understand the legal norms contained in the legislation". The research specifications used in this studyisdescriptive analysis, namely research that shows the enforcement of laws and regulations related to a number of legal theories and the practice of implementing positive law as well as events that exist in actual practice regarding the implementation of bankruptcy implementation. Secondary data is data used through library research on primary, secondary, and tertiary legal materials. After the necessary secondary data has been collected, the legal material can be processed and analyzed using data processing techniques in a qualitative way, namely "decomposing data in 
a quality way in the form of sentence regularity, coherent, logical, nonoverlapping and effective. So it provides easy understanding and interpretation of data.

Sub Title

1. Distribution of Inheritance of Children Out of Wedlock as Substitute Heirs Based on the Civil Code Study of Supreme Court Decision Number

\section{: 784 K/Pdt/2014.}

Based on Article 830 of the Civil Code is: "Inheritance only occurs because of death" (Subekti \& Tjitrosudibio, 1992).

If it is related to the case, then there has been a legal inheritance due to the death of the heir, because the heirs, namely the late Djaja Tjandra and the late Masri Tansa, have died.

Based on Article 832 of the Civil Code(Law of the Republic of Indonesia, 1974) is:

"According to the law, those who are entitled to become heirs are blood relatives, both legal according to the law and outside of marriage, and the husband or wife who has lived the longest, according to the following regulations. If the blood family and the husband or wife who have lived the longest are not present, then all the inheritance becomes the property of the state, which is obliged to pay off the debts of the deceased person, as long as the price of the inheritance is sufficient for that."

When it comes to the case, the heirs of the late Djaja Tjandra with the late Masri Tansa are Murni Tjandra as the first child, Dewina Tjandra as the second child, Trisnani Tjandra as the third child, Patty Tjandra as the fourth child, Sarina Tjandra as the fifth child, Arifin Tjandra as the sixth child, the seventh Ony Tjandra, Fitri Tjandra as the eighth child is the legal heir of the late Djaja Tjandra with the late Masri Tansa.

Based on Article 842 of the Civil Code(Law of the Republic of Indonesia, 1974) is:

"Substitutions that occur in a legitimate straight line downward, continue without end. The substitution is permitted in all cases, both if 
the children and the deceased become joint heirs with the descendants and the child who died first, or if all their descendants inherit together, one with another in a relationship. families of varying degrees."

If it is related to the case, Darwis Tansa and Wilys Tansa as illegitimate children of Murni Tjandra cannot be the substitute heirs of Murni Tjandra because the successor heirs in a straight line down must be legitimate descendants and thus Dervish Tansa and Wilys Tansa are not entitled to the property. The inheritance left by the late Djaja Tjandra and the late Masri Tansa.

Based on the above discussion, the distribution of the inheritance of the late Djaja Tandra and the late Masri Tansa is as follows: HP of Djaja Tjandra and Masri Tansa: 1 for Dewina Tjandra, Trisnani Tjandra, Patty Tjandra, Sarina Tjandra, Arifin Tjandra, Ony Tjandra, Fitri Tjandra.

Each part:

1. Dewina Tjandra : $1 / 7$

2. Trisnani Tjandra $: 1 / 7$

3. Patty Tjandra $: 1 / 7$

4. Sarina Tjandra $: 1 / 7$

5. Arifin Tjandra $: 1 / 7$

6. Ony Tjandra $: 1 / 7$

7. Fitri Tjandra $: 1 / 7$

8. Pure Tjandra : Didn't get it because he died first of the heirs

9. Wilys Tansa : Didn't get because couldn't become an expert successor to Pure Tjandra

10. Dervish Tansa : Didn't get it because couldn't become an Expert

$\begin{array}{ll}\text { successor to Pure Tjandra } \\ \text { TOTAL } & : 7 / 7=1\end{array}$


2. The Supreme Court Decision Number: $784 \mathrm{~K} / \mathrm{Pdt} / 2014$ is in accordance with the Civil Code or not

Based on the contents of the Supreme Court Decision No. 784 $\mathrm{K} / \mathrm{Pdt} / 2014$, the content of the judge's decision is to state that by law the Plaintiff is the legal heir and is entitled to 1/16 (one sixteenth) part of the estate of the late. Djaja Tjandra with the late. Masri Tansa. If this is related to the case, then the division is as follows:

Djaja Tjandra's HP with Masri Tansa $=1$ for Murni Tjandra, Dewina Tjandra, Trisnani Tjandra, Patty Tjandra, Sarina Tjandra, Arifin Tjandra, Ony Tjandra, and Fitri Tjandra. Each gets $=1 / 8$

Because Murni Tjandra died first from the heir and was replaced by Darwis Tansa and Wilys Tansa. The portion of the inheritance received by the late Murni Tjandra is divided by 2 (two) successors, each of whom gets $=$ 1/8: $2=1 / 8 X=1 / 16$.

So, the distribution of the inheritance of the late Djaja Tjandra with the late Masri Tansa is as follows:

1. Dewina Tjandra $: 1 / 8=2 / 16$

2. Trisnani Tjandra $: 1 / 8=2 / 16$

3. Patty Tjandra $\quad: 1 / 8=2 / 16$

4. Sarina Tjandra $: 1 / 8=2 / 16$

5. Arifin Tjandra $: 1 / 8=2 / 16$

6. Ony Tjandra $\quad: 1 / 8=2 / 16$

7. Fitri Tjandra $\quad: 1 / 8=2 / 16$

8. Pure Tjandra : didn't get it because it died more

first from the heir

9. Darwin Tansa $\quad: 1 / 16$

\begin{tabular}{ll} 
10. Wilys Tansa & $: 1 / 16$ \\
\hline Total & $: 16 / 16=1$
\end{tabular}$+$ 
Based on the description above, the contents of the Supreme Court's decision Number $784 \mathrm{~K} / \mathrm{Pdt} / 2014$ part 1 is certainly not in accordance with the Civil Code, because based on Article 842 of the Civil Code which states that only a substitute heir can be legitimate descendants, then Darwis Tansa and Wilys Tansa cannot be the substitute heirs of their mother, namely Murni Tjandra because Darwis Tansa and Wilys Tansa are not legitimate children of Murni Tjandra. Therefore, Darwis Tansa and Wilys Tansa are not entitled to the inheritance of the late Djaja Tjandra and the late Masri Tansa.

\section{Conclusion}

Based on the results of the above discussion, it can be concluded that, (1) in accordance with the contents of Article 830 of the Civil Code, that after the death of the late Djaja Tjandra and the late Masri Tansa, the inheritance is opened to the heirs and those who are entitled to inherit are children children of the heirs, namely Dewina Tjandra, Trisnani Tjandra, Patty Tjandra, Sarina Tjandra, Arifin Tjandra, Ony Tjandra, Fitri Tjandra, and (2) with the division of the contents of the Supreme Court Decision No. 784 K/Pdt/2014 part 1 regarding the distribution of inheritance The late Djaja Tjandra with the late Masri Tansa to his heirs, who decided that Darwis Tansa and Wilys Tansa as illegitimate children could be substitute heirs for their mother, namely Murni Tjandra, in the distribution of the inheritance of the late Djaja Tjandra and the late Masri Tansa, which was not in accordance with the Civil Code.

\section{Bibliography}

\section{Books}

Ali, A. (2000). Inheritance Law Family Law Law of Evidence. Jakarta: PT Rineka Cipta.

Meliala, DS (2018). Inheritance Law According to the Civil Code. Aulia nuance. 
Warin, E. (2011). Inheritance Law, Xth edition. Jakarta: Raja Grafindo Persada.

Pitlo, A., Kasdorp, JE, \& Arief, MI (1979). Inheritance law: according to the Dutch Civil Code Code. Intertime.

Satrio, J. (1992). Inheritance law. Bandung: Image of Aditya Bakti.

Subekti, R., \& Tjitrosudibio, R. (1992). The Civil Code: with the addition of the Basic Agrarian Law and the Marriage Law.

Suparman, E., \& Gunarsa, A. (2005). Indonesian inheritance law: in the perspective of Islam, adat, and BW. PT Refika Aditama.

Tamakiran, S. (2004). Legal Principles According to Three Legal Systems. Bandung: Pioneer Jaya.

\section{JOURNAL ARTICLES:}

Darmabrata, W. (2009). Civil Marriage Law (Requirements for Validity of Marriage, Rights and Obligations of Husband and Wife, Marital Property). Rizkita, Jakarta.

Hilman, H. (2007). Indonesian Marriage Law according to legislation, customary law, religious law. Bandung: Bandar Maju.

Jamal, R. (2016). Bilateral Inheritance Between Heirs of Different Religions in Civil Law and Compilation of Islamic Law. Al-Syir'ah Scientific Journal, 14(1).

Sanjaya, UH (2018). The position of the will with respect to the inheritance that has not been distributed to the heirs. Juridical Journal, 5(1), 67-97.

Setiawan, YK, \& Keumala, D. (2019). Juridical Analysis of the Division of Inheritance of the Late. Lumbangaol To His Heirs Based On The Provisions Of The Civil Code (Study Decision No. 580/PDT. G/2015/PN MDN.). Trisakti Law Reform, 1(1).

Act

1945 Constitution

Code of Civil law

Law Number 1 of 1974 concerning Marriage 